\section{Reduction of Escherichia coli 0157:H7 during manufacture and ripening of Italian semi-dry salami}

\author{
Elena Dalzini, ${ }^{1}$ Elena Cosciani-Cunico, ${ }^{1}$ \\ Paola Monastero, ${ }^{1}$ Chiara Sfameni, ${ }^{1}$ \\ Enrico Pavoni, ${ }^{2}$ Paolo Daminelli, ${ }^{1}$ \\ Marina-Nadia Losio, ${ }^{2}$ Andrea Serraino, ${ }^{3}$ \\ Giorgio Varisco' \\ ${ }^{1}$ Centro di Referenza Nazionale per i \\ Rischi Emergenti in Sicurezza Alimentare, \\ Istituto Zooprofilattico Sperimentale \\ della Lombardia e dell'Emilia Romagna B. \\ Ubertini, Brescia; ${ }^{2}$ Reparto di \\ Microbiologia, Istituto Zooprofilattico \\ Sperimentale della Lombardia e \\ dell'Emilia Romagna B. Ubertini, Brescia; \\ ${ }^{3}$ Dipartimento di Scienze Mediche \\ Veterinarie, Università di Bologna, \\ Ozzano dell'Emilia (BO), Italy
}

\section{Abstract}

In order to simulate a contamination at the processing plant, one batch of freshlyprocessed salami batter $(20 \mathrm{~kg})$ was inoculated (1\% v:w) with 5 log colony forming unit (CFU)/g of a multi-strain cocktail of two strains of Escherichia coli 0157:H7 (registered and wild strain). Another batch was inoculated ( $1 \%$ v:w) with sterile physiological saline solution and used to check the lactic acid bacteria (Lab) behaviour and the changes of physicochemical parameters (pH and $a_{w}$ ). Both batches were then processed to obtain a semi-dry salami (Hungarian-style): microbiological and physico-chemical properties were monitored during 94 days of ripening. During the manufacturing process, the levels of pathogen decreased of about $2.18 \mathrm{log} \mathrm{CFU} / \mathrm{g}$ with respect to the initial inoculated levels. The behaviour of the indigenous bacteria such as Lab and the physico-chemical properties can help to determine the fate of pathogens throughout processing.

\section{Introduction}

Escherichia coli strains isolated from human diseases have been grouped into at least six different diarrhoeagenic $E$. coli groups based on specific virulence factors and phenotypic traits. Strains of Verotoxigenic $E$. coli (VTEC) have become emergent foodborne human pathogens since the first documentation of VTEC 0157:H7 as the infective agent in an outbreak in 1982 (Riley et al., 1983). The first recognised community outbreak of 0157:H7 in Europe occurred in the United Kingdom in the summer of 1985 and further outbreaks and sporadic cases have been reported throughout Europe ever since (Gillespie et al., 2005). In Europe and all over the world several outbreaks of $E$. coli $0157: \mathrm{H} 7$ caused by fermented sausage were reported: in 1994 in the USA, 20 cases were reported and were associated with consumption of drycured sausage (Alexander et al., 1995); in Canada (1998-1999) 182 cases were reported and associated with salami and Genoa salami consumption (Williams et al., 2000; MacDonald et al., 2004); in Sweden (2002) a total of 39 cases was associated with fermented sausages consumption (Sartz et al., 2008). In Italy, a family outbreak of $E$. coli $0157: \mathrm{H} 7$ was microbiologically associated with consumption of dry-fermented salami made with pork meat and produced in a local plant (Conedera et al., 2007).

These epidemiological data evidence that foodborne disease from dry sausages cannot be underestimated and efforts should be made to control contamination at slaughter level and to limit bacterial growth at processing stage (Barbuti and Parolari, 2002). Based on significant contamination rates in raw meat, evaluating the behaviour of $E$. coli $0157: \mathrm{H} 7$ during processing of meat products appear to be another important step to achieve microbial safety (Barbuti and Parolari, 2002).

The objective of the study was therefore to evaluate the behaviour of $E$. coli $0157: H 7$ during processing and ripening of salami, a typical Italian dry-cured sausage.

\section{Materials and Methods}

\section{Bacterial strains}

A reference strain $\left(E\right.$. coli $0157: \mathrm{H} 7$ ATCC $^{\circledR}$ $35150^{\mathrm{TM}}$ ) and a field isolate of $E$. coli $0157: \mathrm{H} 7$ (Ec 72209) isolated from dry sausage and stored in the culture collection of the Veterinary Epidemiology Centre of Brescia, were used in this experimental study. Each strain, previously kept frozen, was transferred ( $2 \%$ inoculum) into brain heart infusion (BHI) broth and incubated at $37^{\circ} \mathrm{C}$ for $24 \mathrm{~h}$ in aerobic conditions. The cultures were centrifuged for $60 \mathrm{~min}$ at $4^{\circ} \mathrm{C}$ at $4000 \mathrm{~g}$ (Jouan centrifuge CR422; Jouan Inc., Winchester, VA, USA); the pellet was washed with sterile physiological solution $\left(\mathrm{H}_{2} \mathrm{O}\right.$ with $\left.0.9 \% \mathrm{NaCl}\right)$, centrifuged as previously described and re-suspended in sterile physiological solution. For each strain, the culture concentration was checked by plate counting on BHI agar. The two strains were combined in equal volumes, serially diluted and inoculated in salami batter to reach
Correspondence: Elena Dalzini, Centro di Referenza Nazionale per i Rischi Emergenti in Sicurezza Alimentare, Istituto Zooprofilattico Sperimentale della Lombardia e dell'Emilia Romagna B. Ubertini (IZSLER), via A. Bianchi 9, 25124 Brescia, Italy.

Tel. +39.030.2290611 - Fax: +39.030.2290542.

E-mail: elena.dalzini@izsler.it

Key words: Italian salami, Escherichia coli 0157:H7 VTEC, Food safety.

Acknowledgements: the authors are grateful to Stefania Ducoli and Alessandro Norton (Reparto di Microbiologia, Istituto Zooprofilattico Sperimentale della Lombardia e dell'Emilia Romagna B. Ubertini, Brescia) for scientific support and technical assistance.

Conflict of interests: the authors declare no potential conflict of interests.

Funding: this study was financially supported by Italian Ministry of Health within the research project Milano Expo 2015: garantire la sicurezza alimentare - valorizzare le produzioni CCM2012EXP02015.

Received for publication: 11 March 2014:

Revision received: 4 June 2014.

Accepted for publication: 6 June 2014.

This work is licensed under a Creative Commons Attribution 3.0 License (by-nc 3.0).

(C)Copyright E. Dalzini et al., 2014

Licensee PAGEPress, Italy

Italian Journal of Food Safety 2014; 3:3226

doi:10.4081/ijfs.2014.3226

approximately 5 log colony forming units (CFU)/gram.

Manufacture of salami, inoculation of salami batter and sampling times

A batter of $40 \mathrm{~kg}$ was prepared by mixing minced pork meat (50\%), beef meat (25\%) and pork lard (25\%) refrigerated at $0-7 \pm 2{ }^{\circ} \mathrm{C}$. During mixing, potassium nitrate (E 252) and sodium nitrate (E 250) (0.03\% both), sodium chloride (3\%), dried skimmed milk (2.5\%), saccarose, sodium ascorbate, black and white pepper and garlic were added.

The batter was divided into two batches of $20 \mathrm{~kg}$ each. The first batch was inoculated with the multi-strain pathogen cocktail ( $1 \% \mathrm{v}: \mathrm{w})$ to obtain a final concentration of about $5 \log$ $\mathrm{CFU} / \mathrm{g}$; the second batch was inoculated with sterile physiological saline ( $1 \% \mathrm{v}: \mathrm{w})$ to obtain control samples.

After inoculation the batter was mixed at room temperature $\left(22 \pm 2^{\circ} \mathrm{C}\right)$ for $5 \mathrm{~min}$ and stuffed into reconstructed casings $(105 \mathrm{~mm}$ bore, about 2-3 kg weight for each piece) and matured according to the following procedure: $12 \mathrm{~h}$ at $23^{\circ} \mathrm{C}$ with no control of relative humid- 
ity (RH), $24 \mathrm{~h}$ at $20^{\circ} \mathrm{C}$ at an average $\mathrm{RH}$ of about $70-85 \%$ followed by a gradual decrease of temperature to $1 \mathrm{l}-12^{\circ} \mathrm{C}$ and increase of $\mathrm{RH}$ to $85 \%$ in 10 days. Salami were then left to ripen at $11-12^{\circ} \mathrm{C}$ and $75-85 \%$ RH up to 94 days from manufacture.

\section{Microbiological and physico-chemi- cal analysis}

Samples were collected from contaminated and control batches in three replicates for each sampling by the batter (day 0 ) and by salami at $6,14,20,42,60,75,82$ and 94 days during ripening. For enumeration of $E$. coli $0157: \mathrm{H7}$ in the contaminated batch, $25 \mathrm{~g}$ of batter/salami were transferred into plastic one-chamber filter stomacher bags (NEOMED, London, UK) and homogenised 1:3 w:v in sterile peptone water (PW) (CONDA, Madrid, Spain) for $3 \mathrm{~min}$ in a Stomacher 400 blender (Seward Medical, London, UK). Decimal dilutions in sterile PW were prepared from each bag and the appropriate dilutions were surface-plated (100 L) onto duplicate plate of selective-differential Mac Conkey Sorbitol Agar added with Cefixime Tellurite supplement (CT-SMAC) (Diagnostic Systems, Holzheim, Germany). Typical pathogen's colonies were counted after aerobic incubation of plates at $37^{\circ} \mathrm{C}$ for $24 \mathrm{~h}$. To verify the absence of $E$. coli $0157: \mathrm{H} 7$ in the raw materials, the presence of $E$. coli $0157: \mathrm{H} 7$ was also investigated in the control batch.

Mesophilic lactic acid bacteria (Lab) were enumerated on control samples by pouring plates of $1 \mathrm{~mL}$ of appropriate dilution in de Man, Rogosa and Sharpe agar (MRS) (Microbiol Diagnostici, Cagliari, Italy) and incubating at $30^{\circ} \mathrm{C}$ for $72 \mathrm{~h}$. Physico-chemical analyses were performed on $10 \mathrm{~g}$ of control samples; the $\mathrm{pH}$ was determined using a $\mathrm{HI}$ 223 Calibration checkTM Microprocessor pH meter (Hanna Instruments, Woonsocket, RI, USA) and the water activity $\left(a_{w}\right)$ was measured at $25^{\circ} \mathrm{C}$ with the $a_{w}$ recorder AquaLab, series 3, Model TE (Decagon Devices, Inc., Pullman, WA, USA) in accordance with ISO 21807:2004 (ISO, 2004).

\section{Statistical analysis}

Microbiological count results were expressed as $\mathrm{CFU} / \mathrm{g}$ and reported as log CFU/g. The average and standard deviations of microbial counts and physico-chemical values were determined from the average of three samples at each sampling time for each batch. Analysis of variance (ANOVA) was carried out to evaluate the difference of $\mathrm{pH}, a_{w}$ and microbial counts at different storage time. Significance was statistically analysed by Student $t$-test at a 95\% confidence interval $(\mathrm{P}<0.05)$ using $\mathrm{R}$ statistical software version 2.7.0 (R Development Core Team, 2008).

\section{Results}

Results of $E$. coli 0157:H7 and Lab count, and physico-chemical properties of the batter and salami during the ripening are shown in Table 1.

The microbiological and physico-chemical properties of salami batter were found to be significantly different from those measured in salami. A significant $(\mathrm{P}<0.05)$ increase of Lab count was observed during the first 6 days of ripening (6.21 to $8.58 \mathrm{Log} \mathrm{CFU} / \mathrm{g}$ ); no significant differences were observed up to the $75^{\text {th }}$ day of ripening and a moderate but significant decrease $(\mathrm{P}<0.05)$ was observed at 82 and 94 days of ripening.

A decrease of the $\mathrm{pH}$ value was observed in the first six days of ripening from an initial value of $5.65 \pm 0.02$ to $4.95 \pm 0.03$ followed by an increase after 42 days of ripening (Table 1). The $a_{w}$ values showed a moderate decrease during seasoning from an initial value of $0.956 \pm 0.007$ to $0.906 \pm 0.021$ at the end of ripening (Table 1).

Examination of not contaminated samples at the beginning of shelf life revealed the absence of natural $E$. coli $0157: \mathrm{H} 7$ contamination in the batter mix. The average values of $E$. coli 0157:H7 log counts in contaminated batches of salami are shown in Table 1 . Starting from values of $5.17 \pm 0.06 \mathrm{log} \mathrm{CFU} / \mathrm{g}$ in the batter, $E$. coli count decreased to $4.75 \pm 0.05$ $\log \mathrm{CFU} / \mathrm{g}$ in the first 6 days of ripening. A gradual decrease of $E$. coli $0157: \mathrm{H} 7$ count was observed throughout the ripening stage of the salami, until reaching a level of $2.99 \pm 0.26 \mathrm{log}$ $\mathrm{CFU} / \mathrm{g}$ at the end of the ripening.

\section{Discussion}

An overall $2.18 \log / \mathrm{CFU}$ reduction was observed in $E$. coli 0157:H7 count during production and ripening of salami. Holck and colleagues (2011) recently reviewed several studies carried out to determine the reduction of VTEC during the production of fermented sausages, in which ingredients or production parameters varied systematically (Riordan et al., 1998; Casey and Condon, 2000; Heir et al., 2010; Duffy and Vanderlinde, 2000). In these studies, different sausages, dry and semi-dry, have been investigated, looking at the effects of varying $\mathrm{pH}$, nitrite concentration, fermentation temperature, degree of drying and ripening time. The main factors influencing the reduction of VTEC in fermented sausages appeared to be the temperature of fermentation and rapid drop of $\mathrm{pH}$; salt content, water content, nitrite and recipes may also have an influence (Holck et al., 2011). Previous works reported an $E$. coli $0157: \mathrm{H} 7$ reduction during production of salami, pepperoni and various other fermented sausages of about 1-2 log, although deeper reductions are also observed (Nissen and Holck, 1998; Faith et al., 1997; Montet et al., 2009). The pH of sausages included in the studies mentioned above, varied from $<4.8$ to 5.2 and fermentation temperatures were in the range of 18 to $36^{\circ} \mathrm{C}$, which is comparable to what reported in this study.

\section{Conclusions}

As a general remark, no single parameter appeared to influence survival of $E$. coli to such an extent that it could be adjusted to give completely safe sausages. Fermentation temperature appeared to be an important factor. An optimal combination of different hurdles

Table 1. Changes of Escherichia coli $0157: \mathrm{H} 7$, lactic acid bacteria, $\mathrm{pH}$ and $\boldsymbol{a}_{w}$ throughout the ripening of semi-dry salami.

\begin{tabular}{|c|c|c|c|c|c|c|c|c|c|}
\hline \multirow[t]{2}{*}{ Parameter } & \multirow[t]{2}{*}{ Batter } & \multicolumn{5}{|c|}{ Salami at different ripening times (days) } & \multirow[b]{2}{*}{75} & \multirow[b]{2}{*}{82} & \multirow[b]{2}{*}{94} \\
\hline & & 6 & 14 & 20 & 42 & 60 & & & \\
\hline $\mathrm{Ec}^{\circ}(\log \mathrm{CFU} / \mathrm{g})$ & $5.17 \pm 0.06^{\mathrm{A}}$ & $4.75 \pm 0.05^{\mathrm{B}}$ & $4.66 \pm 0.10^{\mathrm{BC}}$ & $4.52 \pm 0.05 \mathrm{BC}$ & $4.38 \pm 0.09 \mathrm{c}$ & $3.20 \pm 0.06^{\mathrm{D}}$ & $3.06 \pm 013^{\mathrm{D}}$ & $2.63 \pm 0.08^{\mathrm{E}}$ & $2.99 \pm 0.26^{\mathrm{D}}$ \\
\hline $\mathrm{Lab}^{\circ}(\log \mathrm{CFU} / \mathrm{g})$ & $6.21 \pm 0.13^{\mathrm{A}}$ & $8.58 \pm 0.19^{\mathrm{B}}$ & $8.47 \pm 0.14^{B}$ & $8.51 \pm 0.11^{\mathrm{B}}$ & $8.39 \pm 0.08^{B}$ & $8.17 \pm 0.06^{\mathrm{BC}}$ & $8.12 \pm 0.055^{B C}$ & $7.7 \pm 0.16^{\mathrm{CD}}$ & $7.46 \pm 0.41^{\mathrm{D}}$ \\
\hline $\mathrm{pH}^{\sharp}$ & $5.65 \pm 0.02^{\mathrm{A}}$ & $4.95 \pm 0.03^{\mathrm{B}}$ & $4.92 \pm 0.05^{\mathrm{B}}$ & $4.87 \pm 0.03^{\mathrm{B}}$ & $5.05 \pm 0.09 \mathrm{c}$ & $5.57 \pm 0.20^{\mathrm{C}}$ & $5.59 \pm 0.07^{\mathrm{C}}$ & $5.58 \pm 0.17^{\mathrm{C}}$ & $5.44 \pm 0.06^{\mathrm{C}}$ \\
\hline$a_{w}^{\#}$ & $0.956 \pm 0.007^{\mathrm{A}}$ & $0.925 \pm 0.021^{\mathrm{AB}}$ & $0.940 \pm 0.009^{\mathrm{AB}}$ & $0.921 \pm 0.001^{\mathrm{AB}}$ & $0.938 \pm 0.002^{\mathrm{AB}}$ & $0.916 \pm 0.013^{\mathrm{BC}}$ & $0.901 \pm 0.002^{\mathrm{C}}$ & $0.906 \pm 0.021^{\mathrm{BC}}$ & nd \\
\hline
\end{tabular}

Ec, Escherichia coli 0157:H7; Lab, lactic acid bacteria; $a_{w}$, water activity; nd, not determined. Data represent the average values \pm standard deviation of three replicates samples. ${ }^{\circ}$ Evaluated in contaminated samples; *evaluated in control samples. ${ }^{A-E}$ Means with different uppercase letters within a row for each parameter are significantly different $(\mathrm{P}<0.05)$. 
would increase the safety of the sausages. Since a large number of different sausage types exist, differing profoundly not only in $\mathrm{pH}$, salt content, water content and recipes, but also in production conditions like fermentation temperature and maturation time, such differences must be taken into consideration when trying to validate the safety of specific fermented sausage productions. To ensure that the fermentation and drying process are efficient to reduce or eliminate pathogens, procedures should be validated to demonstrate that they achieve established reduction for specific organisms. Data reported in the present work will be useful for food manufacturers that produce ready-to-eat meat products with similar characteristics. Still, the control of hygienic quality of meat used for salami production should be of primary importance to any producer.

\section{References}

Alexander ER, Boase J, Davis M, Kirchner L, Osaki C, Tanino T, Samadpour M, Tarr P, Goldoft M, Lankford S, Kobyashi J, StehrGreen P, Bradley P, Hinton B, Tighe P, Pearson B, Flores GR, Abbott S, Bryant R, Werner SB, Vugia DJ, 1995. Escherichia coli 0157/H7 outbreak linked to commercially distributed dry-cured salami. Washington and California 1994. Available from: http://www.cdc.gov/mmwr/preview/ mmwrhtml/00036467.htm

Barbuti S, Parolari G, 2002. Validation of manufacturing process to control pathogenic bacteria in typical dry fermented product. Meat Sci 62:323-9.

Casey P, Condon S, 2000. Synergistic lethal combination of nitrite and acid $\mathrm{pH}$ on a verotoxin-negative strain of Escherichia coli 0157. Int J Food Microbiol 55:255-8.

Conedera G, Mattiazzi E, Russo F, Chiesa E,
Scorzato I, Grandesso S, Bessegato A, Fioravanti A, Caprioli A, 2007. A family outbreak of Escherichia coli 0157 haemorrhagic colitis caused by pork meat salami. Epidemiol Infect 135:311-4.

Duffy LL, Vanderlinde, PB, 2000. E-coli and salami manufacture. Meeting the challenge of the ANZFA requirements. Food Aust 52:269-70.

Faith NG, Parniere N, Larson T, Lorang TD, Luchansky JB, 1997. Viability of Escherichia coli 0157:H7 in pepperoni during the manufacture of sticks and the subsequent storage of slices at 21, 4 and $20^{\circ} \mathrm{C}$ under air, vacuum and $\mathrm{CO}_{2}$. Int $\mathrm{J}$ Food Microbiol 37:47-54.

Gillespie IA, 0'Brien SJ, Adak GK, Cheasty T, Willshaw G, 2005. Foodborne general outbreaks of Shiga toxin-producing Escherichia coli 0157 in England and Wales 1992-2002: where are the risks? Epidemiol Infect 133:803-8.

Heir E, Holck AL, Omer MK, Alvseike 0, Hoy M, Mage I, Alvseike 0, L’Abée-Lund TM, Omer MK, Granum PE, Heir E, 2010. Reduction of verotoxigenic Escherichia coli by process and recipe optimisation in dry fermented sausages. Int $\mathrm{J}$ Food Microbiol 141:195-202.

Holck AL, Axelsson L, Rode TM, Høy M, Måge I, Alvseike 0, L'Abée-Lund TM, Omer MK, Granum PE, Heir E, 2011. Reduction of verotoxigenic Escherichia coli in production of fermented sausages. Meat Sci 89:286-95.

ISO, 2004. Microbiology of food and animal feeding stuffs. Determination of water activity. ISO Norm 21807:2004. International Organization for Standardization, Geneva, Switzerland.

MacDonald DM, Fyfe M, Paccagnella A, Trinidad A, Louie K, Patrick D, 2004. Escherichia coli 0157:H7 outbreak linked to salami, British Columbia, Canada, 1999. Epidemiol Infect 132:283.
Montet MP, Christieans S, Thevenot D, Coppet $\mathrm{V}$, Ganet $\mathrm{S}$, Muller MLD, Dunière $\mathrm{L}$, Miszczycha S, Vernozy-Rozand C, 2009. Fate of acid-resistant and non-acid resistant Shiga toxin-producing Escherichia coli strains in experimentally contaminated French fermented raw meat sausages. Int J Food Microbiol 129:264-70.

Nissen H, Holck A, 1998. Survival of Escherichia coli 0157:H7, Listeria monocytogenes and Salmonella kentuky in Norwegian fermented, dry sausage. Food Microbiol 15:273-9.

R Development Core Team, 2008. R: a language and environment for statistical computing. R Foundation for Statistical Computing Publ., Vienna, Austria.

Riley LW, Remis RS, Helgerson SD, McGee HB, Wells JG, Davis BR, Hebert RJ, Olcott ES, Johnson LM, Hargrett NT, Blake PA, Cohen ML, 1983. Hemorrhagic colitis associated with a rare Escherichia coli serotype. New Engl J Med 308:681-5.

Riordan DCR, Duffy G, Sheridan JJ, Eblen BS, Whiting RC, Blair IS, McDowell DA, 1998. Survival of Escherichia coli 0157:H7 during the manufacture of pepperoni. J Food Protect 61:146-51.

Sartz L, De Jong B, Hjertqvist M, Plym-Forshell L, Asterlund R, Löfdahl S, Osterman B, Ståhl A, Eriksson E, Hansson HB, Karpman D, 2008. An outbreak of Escherichia coli 0157:H7 infection in southern Sweden associated with consumption of fermented sausage; aspects of sausage production that increase the risk of contamination. Epidemiol Infect 136:370-80.

Williams RC, Isaacs S, Decou ML, Richardson EA, Buffett MC, Slinger RW, Brodsky MH, Ciebin BW, Ellis A, Hockin J, 2000. Illness outbreak associated with Escherichia coli 0157:H7 in Genoa salami. Can Med Assoc J 162:1409-13. 